\title{
Mobile Phone Addiction, Phubbing, and Depression Among Men and Women: A Moderated Mediation Analysis
}

\author{
Ana Ivanova ${ }^{1} \cdot$ Oleg Gorbaniuk $^{2} \cdot$ Agata Błachnio $^{1} \cdot$ Aneta Przepiórka $^{1}$ • \\ Natalia Mraka ${ }^{3}$ - Viktoria Polishchuk ${ }^{4}$. Julia Gorbaniuk ${ }^{1}$
}

Published online: 7 March 2020

(C) The Author(s) 2020

\begin{abstract}
For several years, the number of studies on the links between excessive mobile phone use and mental health has been increasing. The aim of the study was to establish if there is a relationship between mobile phone addiction and depression in university students and if phubbing is a mediator of this relationship. The authors also tested if this mediation effect was moderated by loneliness and if the model of relationships between these variables was the same in women and in men. The participants were 402 university and college students from Ukraine, aged 17 to $31 ; 74 \%$ of them were women. The authors used the Adapted Mobile Phone Use Habits, the Phubbing Scale, the Center for Epidemiologic Studies Depression Scale, and the Loneliness Scale. The results of the study have shown that higher mobile phone addiction and higher phubbing is associated with a higher level of depressive moods, with phubbing functioning as a mediator of the relationship between mobile phone addiction and depression. A moderator of this mediation is loneliness, the moderation effect being asymmetrically dependent on gender: in men, high loneliness increases the mediating role of phubbing, which more markedly translates into depression, while in women the analyzed mediation effect becomes weaker with an increase in the sense of loneliness (phubbing correlates less strongly with depression).
\end{abstract}

Keywords Phubbing $\cdot$ Mobile phone addiction $\cdot$ Depression $\cdot$ Loneliness $\cdot$ Moderated mediation

The study was financed by the National Science Centre, Poland, grant no. NCN UMO-2017/26/M/HS6/00779

Agata Błachnio

gatta@kul.pl

Extended author information available on the last page of the article 


\section{Introduction}

The number of studies reporting detrimental effects of smartphones on mental and physical health is constantly growing $[4,18,31,37]$. The negative consequences for health in the group of phone and smartphone ${ }^{1}$ addicts are similar to those of Internet and gaming addiction [6, 40]. The aim of the study was to establish if there is a relationship between mobile phone addiction and depression in university students and if phubbing is a mediator of this relationship. We also tested if this effect was moderated by loneliness and if the model of relations between these variables was the same for women and for men.

\section{Mobile Phone Addiction}

Although in the literature there is a debate on whether excessive mobile phone use can be understood as a behavioral addiction [11,27], and although the same phenomenon is referred to by different terms, such as problematic cell-phone/mobile phone use [10,33, 62], cell-phone overuse [50], mobile phone dependence [19], or mobile phone/smartphone addiction [21, 35, $58,60]$, problematic mobile phone use is often conceptualized as a behavioral addiction, characterized by the basic symptoms of addictive behaviors [19, 41, 42, 64]. Regardless of the ongoing debate, smartphone addiction is a spreading phenomenon especially among young people due to their increased social communication frequency, their greater opportunities for making social relationships, and their better skills in using modern technological devices [45]. Although many studies show that women more often have a tendency to use the mobile phone in a problematic way that men $[17,33,55,62]$, there is also evidence that in the group of adolescents men may spend more time using smartphones compared to women [28] or that women and men are at the same risk of problematic smartphone use [7, 22]. Moreover, the results of the studies conducted to date show that smartphone addiction is positively linked with health problems $[33,56]$, psychological problems [59], and psychiatric disorders, particularly depression $[1,26]$. Loneliness is a predictor of smartphone addiction as well $[9,67]$.

\section{Phubbing}

The term "phubbing" is a merger of two words: "phone" and "snubbing." It was coined as part of the Macquarie Dictionary campaign by a group of lexicographers, poets, and authors [48] in order to name the phenomenon of snubbing the interlocutor in the context of social contact by devoting one's attention to the mobile phone instead of focusing on the person one is talking to. ${ }^{2}$ Phubbing manifests itself in focusing on the phone while talking to a person whom the contents in the phone do not concern [20,35, 47]. Previous studies have shown that phubbing is positively correlated with mobile phone addiction [20,35], which in turn is used as a tool helping in situations of loneliness, anxiety, and worry, and with deprivation in situations of being far from one's phone [35]. Phubbing, however, not only does not help but actually aggravates phubbers' problems: smartphones increase the sense of exclusion from the social environment during smartphone use [36]. Phubbed individuals experience social exclusion too, which in turn increases their need to be in the center of attention in their important

\footnotetext{
"In this project, we use the terms "smartphone" and "mobile" interchangeably. Whenever we say "mobile" we think about a phone with access to the Internet.

${ }^{2}$ http://stopphubbing.com
} 
reference groups and induces them to use social media in order to reduce the sense of exclusion [23]. Research shows that phubbing is positively correlated with loneliness [12], understood as protracted and negatively valenced feeling of social exclusion [49]. Moreover, previous studies have shown that gender can be a moderator of the relationships between phubbing and mobile phone, SMS, social media, and Internet addictions; in the female group, phubbing was related to mobile, SMS, and social media addictions, whereas in the male group it was associated with Internet and gaming addictions [35], with women usually scoring higher than men on phubbing $[3,12,20]$. This means that in the female group smartphones are more often used to facilitate social interactions, whereas in the male group mobile phones perform instrumental functions $[4,55]$. As is the case with smartphone addiction, phubbing is related to mental health: indirect and direct positive associations have been found between phubbing and depression in various age groups $[22,54,63]$.

\section{Depression and Loneliness}

Depressive disorders manifest themselves in sadness, a sense of emptiness, or irritability; these symptoms are accompanied by somatic and cognitive changes significantly affecting the individual's functioning [43]. Also stress plays an important role in the emergence of depression [8]. Studies show that people who more often experience depressive symptoms more often suffer from social media addiction; for instance, it has been found that depression is positively related to Facebook addiction [13], mobile phone addiction $[1,26]$, and phubbing $[22,54,63]$. Moreover, studies show that there is a positive relationship between depression and the sense of loneliness [5, 15, 53]. Ayas and Horzum [2] found that loneliness as well as depression and self-esteem were related to Internet addiction. It has also been established that loneliness is a positive predictor of Facebook addiction [14] and mobile phone addiction [62].

\section{Aim of the Study}

Phubbing is a relatively new phenomenon, which is why, to our knowledge, there are no studies in the literature so far investigating more complex relationships between mobile phone addiction, phubbing, depression, loneliness, and gender. However, based on the studies conducted to date, such as those in the field of new media psychology, it is possible to predict that relationships between these variables do exist. The aim of the present study was to determine the relationships between mobile phone addiction and depression, with phubbing as the mediator of this relationship. We also tested if this mediation effect was moderated by loneliness and if the model of relationships between these variables was the same in women and in men. To our knowledge, in previous studies little space was devoted to the role of gender as a moderator in the relations of phubbing to its determinants and antecedents, and it is these relations that constituted the main object of interest in our research. Figure 1 schematically presents the expected relationships. We tested the postulated model among mobile phone users in Ukraine, where the number of mobiles per 100 inhabitants is one of the highest in Central and Eastern Europe and stands at 135 [46]. According to statistics, 52\% of people in Ukraine use the Internet, which means that this country ranks 110th among 208 countries in the world. ${ }^{3}$ We hypothesized that mobile phone addiction would be positively correlated with

\footnotetext{
${ }^{3} \mathrm{https}: / /$ en.wikipedia.org/wiki/List_of_countries_by_number_of_Internet_users
} 


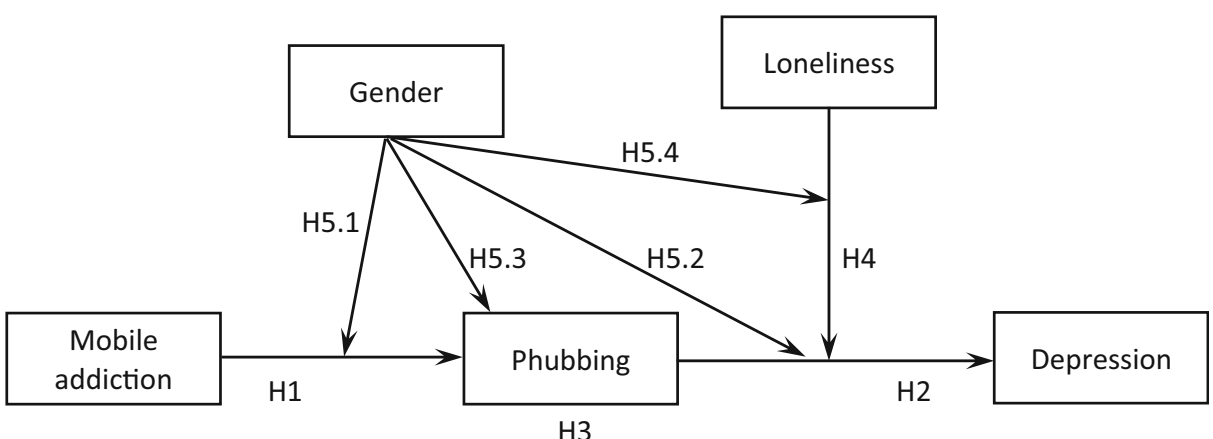

H3

Fig. 1 The conceptual model of the relationship between mobile phone addiction, phubbing, and depression

phubbing and depression (H1) and that phubbing would also be positively correlated with depression (H2). We predicted that the relationship between mobile phone addiction and depression would be mediated by phubbing (H3) and that the strength of this mediation would be moderated by loneliness (H4). Finally, we expected that the relationships between mobile phone addiction, phubbing, depression, and loneliness would be different in women and in men (H5). Another aim of the study was to check if there were differences between men and women in the levels of phubbing and mobile phone addiction in the population of Internet users in Ukraine.

\section{Method}

\section{Participants and Procedure}

The participants in the study were 402 university and college students from Ukraine, aged 17 to $31(M e=20$ years $) ; 74.1 \%$ of them were women. As many as $91.1 \%$ of the students were single, $7.9 \%$ were married, and $1.0 \%$ were divorced. The mean reported Internet use time was $M=5.26 \mathrm{~h}$ per day on weekdays $(M e=4.5 \mathrm{~h}, S D=3.55 \mathrm{~h})$ and $M=5.77 \mathrm{~h}$ per day on weekends $(M e=5.0 \mathrm{~h}, S D=3.66 \mathrm{~h})$. The tested sample makes it possible to identify the correlation of $r>.15$ between the variables as well as differences of Cohen's $d>0.30$ between the means at the significance level of $\alpha=.05$ with a power of $1-\beta=0.90$. The research was conducted as an Internet survey, from April to June 2017. The link to the website with the questionnaires was sent out to potential respondents. The respondents answered the questions by clicking the appropriate response option. In the case of no answers, the server reminded them to go back and give the missing ones. The participants received no remuneration and were informed that their anonymity would be ensured.

\section{Measures}

The measures used were translated into Ukrainian by two translators and then back-translated; the discrepancies in translation were discussed, and we chose the version that was the best measure of the operationalized variable. 


\section{Measurement of Mobile Phone Addiction}

To measure mobile phone addiction, we administered the Adapted Mobile Phone Use Habits (AMPUH; [61]). It consists of 10 items (example item: Do you lie to others about how much you use your cell phone?), which the participants rate on a 5-point scale from 1 - never to 5 always. The internal consistency of the original version of the AMPUH is $\alpha=.75$. The internal consistency of the version adapted into Ukrainian was $\alpha=.65$.

\section{Measurement of Phubbing}

To measure phubbing, we used the Phubbing Scale [35]. This instrument consists of 10 items (example item: I'm busy with my mobile phone when I'm with friends), which the subjects respond to on a 5-points scale from 1 - never to 5 -always. It comprises two dimensions: Communication Disturbance and Phone Obsession. A high score on the Communication Disturbance subscale means that, being preoccupied by his or her own mobile in other people's presence, the person interrupts the process of face-to-face communication. A high score on the Phone Obsession subscale indicates that the respondent constantly needs to have a smartphone at hand when there is not enough face-to-face communication. The internal consistency of the former subscale in the original version of the measure is $\alpha=.87$, and the internal consistency of the latter subscale is $\alpha=.85$. The internal consistency of these subscales adapted into Ukrainian is $\alpha=.77$ for Communication Disturbance and $\alpha=.72$ for Phone Obsession.

\section{Measurement of Depression}

To measure depression, we used the short form of the Center for Epidemiologic Studies Depression Scale (S-CES-D) [29, 51], which consists of 10 items measuring the level of depression (e.g., I had trouble keeping my mind on what I was doing. I had a crying spell). The participants are asked how often they have felt in the ways described during the past week. They indicate their responses on a 4-point scale: rarely or none of the time (less than 1 day), some or a little of the time (1-2 days), occasionally or a moderate amount of time (3-4 days), most or all of the time (5-7 days). The internal consistency of the Ukrainian version of the scale was $\alpha=.80$.

\section{Measurement of Loneliness}

To measure the level of loneliness, we used the De Jong Gierveld Loneliness Scale [24, 25], which consists of 11 items (e.g., I miss having a really close friend) rated on a 6-point scale. Depending on the study, the internal consistency of the original scale ranges between $\alpha=.80$ and $\alpha=.90$. The homogeneity of the measure also varies across studies, with Loevinger's $H$ ranging between .30 and .50 [25]. The internal consistency of the Ukrainian adaptation was $\alpha=.85$.

\section{Statistical Analyses}

The relationships between pairs of variables were assessed by means of Pearson's $r$ coefficient. To test the differences between the groups in the measurements carried out in the study, we performed a $t$-test. Moderation tests for the relationships between the variables and mediation tests were performed by means of Hayes's [32] algorithm with bootstrapping. 


\section{Results}

Table 1 shows descriptive statistics and correlations between the variables: mobile addiction, phubbing (communication disturbance and mobile obsession), depression, and loneliness for the whole sample and for both sexes. We also checked if there were differences between men and women in terms of the variables measured in the present study. The results of the $t$-test showed that women and men did not differ significantly in terms of mobile phone addiction $(t(400)=0.32, p=.753)$, communication disturbance $(t(400)=1.41, p=.158)$, depression $(t(400)=0.81, p=.420)$, and loneliness $(t(400)=1.39, p=.166)$. We observed higher phone obsession in women $(2.80(S D=0.86)$ vs. $2.47(S D=0.76), t(400)=3.44, p<.001, d=0.34)$.

We found that mobile phone addiction and communication disturbance were positively related to both depression and loneliness, while mobile obsession was positively related only to depression. The results of analyses also revealed that mobile phone addiction correlated with communication disturbance $(r=.49, p<.001)$ and phone obsession $(r=.47, p<.001)$ : the higher the addiction, the higher the phubbing — which confirms hypothesis H1. Moderation effect testing revealed that gender did not moderate the relationship between these variables (communication disturbance: $F(1,398)=0.19, p=.664$; phone obsession: $F(1,398)=2.62$, $p=.106$ ), which means hypothesis H5.1 was not confirmed. In the whole sample we found a statistically significant relationship between phubbing and depression: communication disturbance caused by phone use $(r=.21, p<.01)$ and phone obsession $(r=.18, p<.01)$ translate into a higher level of depression, which confirms hypothesis H2. Also in this case gender was not a moderator of the relationship between these variables (communication disturbance: $F(1$, $398)=0.13, p=.721$; phone obsession: $F(1,398)=0.13, p=.716)$, which means hypothesis H5.2 was not confirmed.

The next step was mediation and moderation analysis, in which we tested the mediation effect using the bootstrapping method. The analysis revealed that the relationship between mobile phone addiction and depression was mediated by communication disturbance $(b=$

Table 1 Pearson's r correlations between the study variables for men, women, and the whole sample

\begin{tabular}{|c|c|c|c|c|c|c|c|c|}
\hline & & \multirow[b]{2}{*}{ Variables } & \multicolumn{2}{|c|}{ Descriptive stats } & \multicolumn{4}{|c|}{ Pearson's $r$ correlation coefficients } \\
\hline & & & $M$ & $S D$ & 1 & 2 & 3 & 4 \\
\hline \multirow[t]{5}{*}{ Whole sample } & 1 & Mobile Addiction & 2.00 & 0.53 & - & & & \\
\hline & 2 & Communication disturbance & 1.90 & 0.60 & $0.49 * *$ & - & & \\
\hline & 3 & Phone obsession & 2.72 & 0.85 & $0.47 * *$ & $0.61 * *$ & - & \\
\hline & 4 & Depression & 2.11 & 0.58 & $0.19 * *$ & $0.21 * *$ & $0.18 * *$ & - \\
\hline & 5 & Loneliness & 3.03 & 0.77 & $0.19 * *$ & $0.12 *$ & 0.02 & $0.49 * *$ \\
\hline \multirow[t]{5}{*}{ Men } & 1 & Mobile Addiction & 2.01 & 0.54 & - & & & \\
\hline & 2 & Communication disturbance & 1.93 & 0.61 & $0.51 * *$ & - & & \\
\hline & 3 & Phone obsession & 2.80 & 0.86 & $0.50 * *$ & $0.61 * *$ & - & \\
\hline & 4 & Depression & 2.12 & 0.60 & $0.19 * *$ & $0.21 * *$ & $0.17 * *$ & - \\
\hline & 5 & Loneliness & 3.00 & 0.76 & $0.19 * *$ & $0.12 *$ & 0.04 & $0.46^{* *}$ \\
\hline \multirow[t]{5}{*}{ Women } & 1 & Mobile Addiction & 1.99 & 0.50 & - & & & \\
\hline & 2 & Communication disturbance & 1.83 & 0.59 & $0.44 * *$ & - & & \\
\hline & 3 & Phone obsession & 2.47 & 0.76 & $0.35 * *$ & $0.59 * *$ & - & \\
\hline & 4 & Depression & 2.07 & 0.53 & 0.19 & 0.18 & $0.21 *$ & - \\
\hline & 5 & Loneliness & 3.13 & 0.79 & 0.19 & 0.12 & 0.01 & $0.59 * *$ \\
\hline
\end{tabular}

$* p<0.05, * * p<0.01$ 
0.065 , boot $S E=0.034,90 \%$ CI $[0.013,0.125])$, whereas phone obsession was not a statistically significant mediator $(b=0.029$, boot $S E=0.031,90 \%$ CI $[-0.021,0.082])$. This means that hypothesis H3, postulating the mediation of the relationship between mobile phone addiction and depression by phubbing was confirmed for communication disturbance. We also found that gender moderated the mediation effect neither in the case of communication disturbance (index $=-0.057$, boot $S E=0.076,90 \%$ CI $[-0.177,0.068]$ ) nor in the case of phone obsession (index $=0.035$, boot $S E=0.066,90 \%$ CI $[-0.069$, 0.148]). This means that hypothesis H5.3, postulating that gender is a moderator of the mediation of the relationship between mobile phone addiction and depression by phubbing, was not confirmed.

Next, we tested if loneliness was a moderator of the mediation of the relationship between mobile phone addiction and depression (see Fig. 1). Test results showed that the moderated mediation was statistically significant neither in the case of communication disturbance (index $=-0.048$, boot $S E=0.038,90 \%$ CI $[-0.111,0.014]$ ) nor in the case of phone obsession (index $=-0.001$, boot $S E=0.037$, 90\% CI [ -0.063 , $0.059])$. Finally, we tested if gender moderated the moderation of the mediation presented in Fig. 1 (hypothesis H5.4). Test results showed that gender was a statistically significant moderator of the moderation of mediation in the case of phone obsession (index $=0.147$, boot $S E=0.083,90 \%$ CI $[0.013,0.283]$ ). This means that, in men, an increase in loneliness is accompanied by an increase in the mediating role of phone obsession in the intensification of depressive symptoms: the effect increases from $b=0.018$ (boot $S E=0.058$ ) at low loneliness to $b=0.143$ (boot $S E=0.074$ ) at high loneliness. In women, the direction of the moderation of mediation by loneliness is the opposite: at low loneliness, phone obsession mediates the relationship between mobile phone addiction and depression more strongly $(b=0.083$, boot $S E=0.053)$, whereas at high loneliness the mediation effect disappears $(b=0.020$, boot $S E=$ 0.051). In the case of communication disturbance, the tested moderation was not statistically significant (index $=-0.044$, boot $S E=0.084$, 90\% CI $[-0.181,0.093]$ ). This means that hypothesis H5.4. was confirmed in the case of phone obsession as a mediator. Figure 2 sums up the relationships found between the variables.

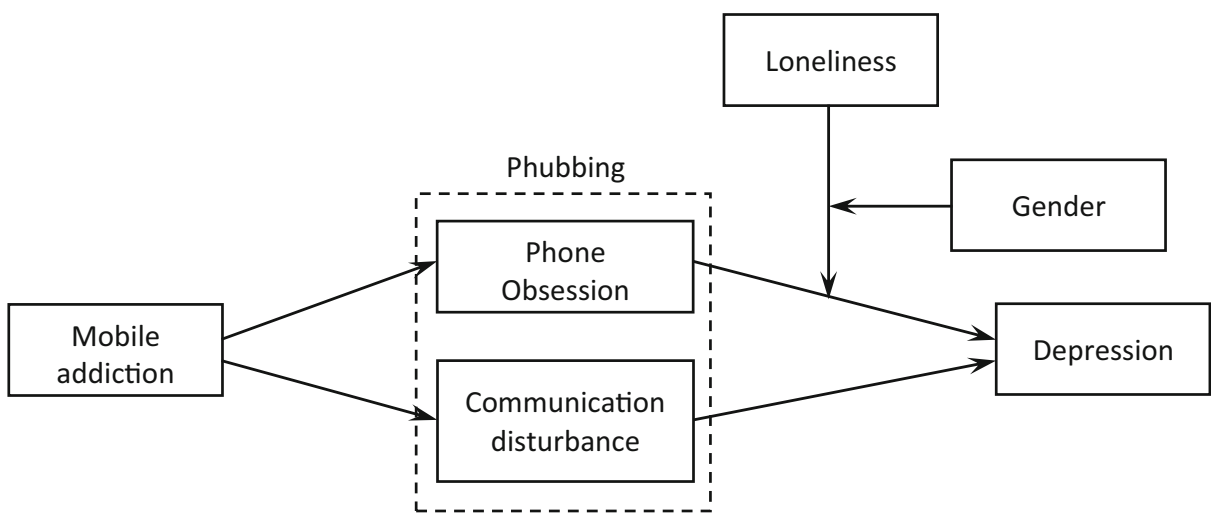

Fig. 2 The final model of the relationship between mobile phone addiction and depression, with the mediating role of phubbing and the moderating role of loneliness and gender 


\section{Discussion}

The main aim of the study was to establish if there is a relationship between mobile phone addiction and depression in university and college students and if phubbing is a mediator of this relationship. To our knowledge, this was the first study to investigate such relations between the variables. We found that the higher were the levels of mobile phone addiction and phubbing, the higher was the level of depressive moods; we also established that phubbing functioned as a mediator of the relationship between mobile phone addiction and depression. A moderator of this mediation is loneliness, the moderation effect being asymmetrically dependent on gender: in men, high loneliness increases the mediating role of phubbing, which more markedly translates into depression, while in women the analyzed mediation effect becomes weaker with an increase in the sense of loneliness (phubbing correlates less strongly with depression).

Mobile phone addiction is positively correlated with phubbing and depression (Hypothesis 1); phubbing is positively correlated with depression as well (Hypothesis 2). The obtained results are consistent with previous research reports: positive relationships have been observed between mobile phone addiction and depressive symptoms [1,26], between phubbing and depression [22, 54, 63], and between mobile phone addiction and phubbing [20, 35]. The possible causes of the emergence of depression in a situation of Internet addiction were identified by Kraut et al. [38]: Internet use negatively affects well-being, which suggests that Internet addiction may lead to depression. Similar patterns have been detected in the case of smartphone use, with interpersonal relations additionally taken into account: phubbing indirectly increases the symptoms of depression by decreasing relationship satisfaction and life satisfaction [54]; moreover, partner's phubbing indirectly contributes to depression by decreasing relationship satisfaction [63].

Mobile phone addiction increases the symptoms of depression through communication disturbance, but phone obsession is not a statistically significant mediator of this relationship (Hypothesis 3). The sense of loneliness moderates the strength of this mediation neither in the case of communication disturbance nor in the case of phone obsession (Hypothesis 4), which seems to be a surprising result in the context of the literature on the subject. The possible cause of the established patterns may be the relationship between phubbing, social exclusion, and depression. A high score on the Communication Disturbance subscale means that, being preoccupied by his or her mobile in other people's presence, the person interrupts the process of face-to-face communication. The results of the studies conducted to date show that ignoring the interlocutor(s) by using a smartphone in their presence may increase the sense of exclusion from the social environment [36]. Social exclusion may in turn increase the symptoms of depression [39].

Since there are not many reports on the moderating role of gender differences in the literature, in the present study we tested if gender played the role of a moderator for the relationships between the variables. The testing of the role of gender as a moderator revealed that it did not moderate the relationship between mobile phone addiction and phubbing (Hypothesis 5.1). In several previous studies researchers tested the moderating role of gender in the relationship between mobile phone addiction and phubbing and obtained contradictory results. Karadağ et al. [35] found that gender moderated the relationship between mobile phone addiction and phubbing (the relationship was stronger for women than for men), while in the study by Chotpitayasunondh and Douglas [20] gender was not a statistically significant moderator of the same relationship. In our study, we also found that gender did not moderate 
the relationship between phubbing and depression (Hypothesis 5.2). In previous studies gender was not tested as a moderator of the relationship between phubbing and depression, but there have been attempts to detect associations between similar variables. For example, SánchezMartínez and Otero [59] established that, of many other variables, depression and gender (female) were predictors of problematic smartphone use [59].

When testing more complex relationships between the variables in the present study, we have established that gender does not moderate the mediating effect of phubbing in the relationship between mobile phone addiction and depression (Hypothesis 5.3). We have also established that in the case of communication disturbance the mediating role of phubbing is independent of the person's gender and loneliness. In the case of phone obsession, by contrast, the mediating role of phubbing depends on the interaction of loneliness and gender (Hypothesis 5.4). In the case of lonely men, mobile phone addiction increases the symptoms of depression through phone obsession. In women, the mediating role of obsession is weaker and has the opposite direction: as loneliness increases, phone obsession ceases to mediate the relationship between mobile phone addiction and depression. These patterns can be explained in the light of the purposes for which women and men use smartphones. For men the smartphone is a device serving pragmatic functions, while for women it serves the purpose of contacting other people $[4,34,55]$. For this reason, mobile obsession - preoccupation with the phone when there is not enough face-to-face contact - in the group of women who feel lonely probably means communicating with others by means of the smartphone, which leads to a decrease in the sense of social exclusion and thus contributes to the weakening of depressive symptoms (cf. [39]). In the group of lonely men, by contrast, mobile obsession may more often manifest itself in the form of excessive Internet use or gaming, which in turn may increase the symptoms of depression $[16,38]$.

Research results have shown that women and men do not differ in the level of smartphone addiction. In the literature on the subject, the predominant results are those according to which women have a stronger tendency to use mobile phones in problematic ways compared to men $[33,62]$. Our study is consistent with the results reported by Bianchi and Phillips [7] and by Davey et al. [22], who also found no differences between representatives of different genders in terms of problematic mobile phone use. Other studies, which revealed no differences between women and men, focused on selected aspects of mobile phone addiction: social networking on smartphones [57] or textmessaging dependency [44]. The cause of the absence of differences in smartphone addiction between women and men may be the fact that the question of the relationship between gender and addiction to technology remain open: although it is men rather than women who use the computer and the Internet in problematic ways more often [30,65], the profile of a person experiencing problems associated with the use of technology changes with the passage of time [66]; women's attitudes to technology also change, evolving towards more positive ones [52]. According to Bianchi and Phillips [7], the original gender differences are a product of socialization and access to technology; it is possible that with time these differences will begin to disappear.

The measurement of the level of phubbing also revealed no differences between women and men in scores on the Communication Disturbance subscale, and in the group of women we observed higher phone obsession. In previous studies in which the same measure was used, the results varied: Błachnio and Przepiórka [12] observed higher scores on both phubbing subscales in the case of women, whereas Davey et al. [22] found no differences whatsoever between women and men. A high score on the Phone 
Obsession subscale indicates that the respondent constantly needs to have a smartphone at hand when there is not enough face-to-face communication [35]. It is possible that the differences between women and men in the level of phone obsession stem from the fact that women perceive technological devices - such as smartphones or the Internet mainly as communication tools, as opposed to men, for whom technological devices perform pragmatic functions (e.g., looking for information, entertainment) [4, 34, 55]. Therefore, when there is not enough face-to-face communication, women use smartphones for mediated communication more often than men do.

\section{Limitations and Future Studies}

The study presented in this paper has several limitations. Firstly, the sample was narrowed down to university and college students. It is commonly known that smartphone users belong to various age groups, which means the problems of mobile phone addiction or phubbing may concern not only students - as has been demonstrated in the studies conducted to date [54, 63]. Therefore, our suggestion for the future is to test a sample representing the full age range in order to check how age moderates the established patterns. Secondly, the study followed a cross-sectional design, which means the obtained results cannot be interpreted as showing cause-and-effect relationships. Given the limitations of the present study, our suggestion for the future is to design and conduct a longitudinal study that will make it possible to look more closely into the relationships between smartphone addiction, phubbing, and depression. Thirdly, the presented study was conducted in Ukraine, and research should be extended to other countries in order to check if the relationships we have found are universal or specific to only some of the countries.

\section{Conclusion}

To sum up, the main aim of this study was to determine the links between mobile phone addiction and depression in university and college students and to establish if phubbing is a mediator of this relationship. We also tested if this mediation effect was moderated by loneliness and if the model of relationships between these variables was the same in women and in men. We have found that mobile phone addiction and phubbing are positively associated with depression, with phubbing functioning as a mediator of the relationship between mobile phone addiction and depression. A moderator of this mediation is loneliness; interestingly, the moderation effect is asymmetrically dependent on gender. The present study is a step on the way towards a better understanding of the phenomena of phubbingu and mobile phone addiction. Above all, its results point to the role of gender in the emergence of both phenomena and may inspire further research.

\section{Compliance with Ethical Standards}

Human Participants All procedures performed in studies involving human participants were in accordance with the ethical standards of the institutional and/or national research committee and with the 1964 Helsinki declaration and its later amendments or comparable ethical standards.

Informed Consent Informed consent was obtained from all individual participants included in the study. 
Open Access This article is licensed under a Creative Commons Attribution 4.0 International License, which permits use, sharing, adaptation, distribution and reproduction in any medium or format, as long as you give appropriate credit to the original author(s) and the source, provide a link to the Creative Commons licence, and indicate if changes were made. The images or other third party material in this article are included in the article's Creative Commons licence, unless indicated otherwise in a credit line to the material. If material is not included in the article's Creative Commons licence and your intended use is not permitted by statutory regulation or exceeds the permitted use, you will need to obtain permission directly from the copyright holder. To view a copy of this licence, visit http://creativecommons.org/licenses/by/4.0/.

\section{References}

1. Augner C, Hacker GW. Associations between problematic mobile phone use and psychological parameters in young adults. Int J Public Health. 2012;57(2):437-41. https://doi.org/10.1007/s00038-011-0234-z.

2. Ayas T, Horzum M. Relation between depression, loneliness, self-esteem and internet addiction. Education. 2013;133(3):283-90.

3. Balta S, Emirtekin E, Kircaburun K, Griffiths. Neuroticism, trait fear of missing out, and phubbing: the mediating role of state fear of missing out and problematic Instagram use. Int $\mathrm{J}$ Ment Heal Addict. 2018;2018:1-12. https://doi.org/10.1007/s11469-018-9959-8.

4. Baron NS, Campbell EM. Gender and mobile phones in cross-national context. Lang Sci. 2012;34(1):1327. https://doi.org/10.1016/j.langsci.2011.06.018.

5. Baumeister RF, Tice DM. Anxiety and social exclusion. J Soc Clin Psychol. 1990;9(2):165-95. https://doi. org/10.1521/jscp.1990.9.2.165.

6. Beranuy M, Oberst U, Carbonell X, Chamarro A. Problematic internet and mobile phone use and clinical symptoms in college students: the role of emotional intelligence. Comput Hum Behav. 2009;25(5):1182-7. https://doi.org/10.1016/j.chb.2009.03.001.

7. Bianchi A, Phillips JG. Psychological predictors of problem mobile phone use. CyberPsychol Behav. 2005;8(1):39-51. https://doi.org/10.1089/cpb.2005.8.39.

8. Bianchi R, Schonfeld IS, Laurent E. Is burnout a depressive disorder? A reexamination with special focus on atypical depression. Int J Stress Manag. 2014;21(4):307-24. https://doi.org/10.1037/a0037906.

9. Bilgin M, Ishiklar A, Bilgin M, Kaya T. Examination of the predictor variances of the mobile phone addiction on adolescents. In: Ishiklar A, editors. International Journal of Humanities and Social Development Research. Hestourex World Health Sport Tourism Congress \& Exhibition. Baku: IJHSDR; 2017. p. 421-434.

10. Billieux J, Van Der Linden M, Rochat L. The role of impulsivity in actual and problematic use of the mobile phone. Appl Cogn Psychol. 2008;22(9):1195-210. https://doi.org/10.1002/acp.1429.

11. Billieux J, Maurage P, Lopez-Fernandez O, Kuss DJ, Griffiths MD. Can disordered mobile phone use be considered a behavioral addiction? An update on current evidence and a comprehensive model for future research. Curr Addict Rep. 2015;2(2):156-62. https://doi.org/10.1007/s40429-015-0054-y.

12. Błachnio A, Przepiórka A. Be aware! If you start using Facebook problematically you will feel lonely: Phubbing, loneliness, self-esteem, and Facebook intrusion. A cross-sectional study. Soc Sci Comput Rev. 2018. https://doi.org/10.1177/0894439318754490.

13. Błachnio A, Przepiórka A, Pantic I. Internet use, Facebook intrusion, and depression: results of a crosssectional study. Eur Psychiat. 2015;30(6):681-684.

14. Błachnio A, Przepiorka A, Boruch W, Bałakier E. Self-presentation styles, privacy, and loneliness as predictors of Facebook use in young people. Personal Individ Differ. 2016;94(5):26-31. https://doi. org/10.1016/j.paid.2015.12.051.

15. Brage D, Meredith W, Woodward J. Correlates of loneliness among Midwestern adolescents. Adolescence. 1993;28(111):685-93. https://doi.org/10.1002/acp.1429.

16. Brunborg GS, Mentzoni RA, Frøyland LR. Is video gaming, or video game addiction, associated with depression, academic achievement, heavy episodic drinking, or conduct problems? J Behav Addict. 2014;3(1):27-32. https://doi.org/10.1556/JBA.3.2014.002.

17. Chiu SI, Hong FY, Chiu SL. An analysis on the correlation and gender difference between college students' internet addiction and mobile phone addiction in taiwan. ISRN Addiction, 2013;360607. https://doi. org/10.1155/2013/360607.

18. Chóliz M. Mobile phone addiction: a point of issue. Addiction. 2010;105(2):373-4. https://doi.org/10.1111 /j.1360-0443.2009.02854.x.

19. Chóliz M. Mobile-phone addiction in adolescence: the test of Mobile-phone dependence (TMD). Prog Health Sci. 2012;2(1):33-44. https://doi.org/10.3389/fpsyg.2016.00650. 
20. Chotpitayasunondh V, Douglas KM. How "phubbing" becomes the norm: the antecedents and consequences of snubbing via smartphone. Comput Hum Behav. 2016;63(C):9-18. https://doi.org/10.1016/j. chb.2016.05.018.

21. Davey S, Davey A. Assessment of smartphone addiction in Indian adolescents: a mixed method study by systematic-review and meta-analysis approach. Int J Prev Med. 2014;5(12):1500-11.

22. Davey S, Davey A, Raghav SK, Singh JV, Błachnio A, Przepiórka A. Predictors and consequences of "Phubbing" among adolescents and youth in India: an impact evaluation study. J Fam Community Med. 2018;25(1):35-42. https://doi.org/10.4103/jfcm.jfcm 7117.

23. David ME, Roberts JA. Phubbed and alone: phone snubbing, social exclusion, and attachment to social media. J Assoc Consum Res. 2017;2(2):155-63. https://doi.org/10.1086/690940.

24. De Jong Gierveld J, Kamphuis F. The development of a RaschType loneliness scale. Appl Psychol Meas. 1985;9(3):289-99. https://doi.org/10.1177/014662168500900307.

25. De Jong Gierveld J, Van Tilburg TG. Manual of the loneliness scale. Amsterdam: VU University; 1999.

26. Demirci K, Akgönül M, Akpinar A. Relationship of smartphone use severity with sleep quality, depression, and anxiety in university students. J Behav Addict. 2015;4(2):85-92. https://doi.org/10.1556 /2006.4.2015.010.

27. De-Sola Gutiérrez J, de Fonseca FR, Rubio G. Cell-phone addiction: a review. Frontiers in Psychiatry. 2016;7:175. https://doi.org/10.3389/fpsyt.2016.00175.

28. Devís-Devís J, Peiró-Velert C, Beltrán-Carrillo VJ, Tomás JM. Screen media time usage of 12-16 year-old Spanish school adolescents: effects of personal and socioeconomic factors, season and type of day. $\mathrm{J}$ Adolesc. 2009;32(2):213-31. https://doi.org/10.1016/j.adolescence.2008.04.004.

29. Eaton WW, Smith C, Ybarra M, Muntaner C, Tien A. Center for Epidemiologic Studies Depression Scale: review and revision (CESD and CESD-R). In: Maruish ME, editor. The use of psychological testing for treatment planning and outcomes assessment: instruments for adults. Mahwah: Lawrence Erlbaum Associates Publishers; 2004. p. 363-77.

30. Griffiths MD, Hunt N. Dependence on computer games by adolescents. Psychol Rep. 1998;82:475-80. https://doi.org/10.2466/pr0.1998.82.2.475.

31. Ha JH, Chin B, Park DH, Ryu SH, Yu J. Characteristics of excessive cellular phone use in Korean adolescents. CyberPsychol Behav. 2008;11(6):783-4. https://doi.org/10.1089/cpb.2008.0096.

32. Hayes AF. Introduction to mediation, moderation, and conditional process analysis: a regression-based approach. New York: The Guilford Press; 2013.

33. Jenaro C, Flores N, Gómez-Vela M, González-Gil F, Caballo C. Problematic internet and cell-phone use: psychological behavioral, and health correlates. Addict Res Theory. 2007;15(3):309-20. https://doi. org/10.1080/16066350701350247.

34. Junco R, Merson D, Salter DW. The effect of gender, ethnicity, and income on college students' use of communication technologies. Cyber Psychol Behav Soc Netw. 2010;13(6):619-27. https://doi.org/10.1089 /cyber.2009.0357.

35. Karadağ E, Tosuntas SB, Erzen E, Duru P, Bostan N, Sahin BM, et al. Determinants of phubbing, which is the sum of many virtual addictions: a structural equation model. J Behav Addict. 2015;4(2):60-74. https://doi.org/10.1556/2006.4.2015.005.

36. Karadağ E, Tosuntaș ȘB, Erzen E, Duru P, Bostan N, Mızrak Șahin B, Babadağ B. The virtual world's current addiction: Phubbing. Addicta: Turkish J Addict. 2016;3(2):250-269. https://doi.org/10.15805 /addicta.2016.3.0013

37. Khan M. Adverse effects of excessive mobile phone use. Int J Occup Med Environ Health. 2008;21(4):28993. https://doi.org/10.2478/v10001-008-0028-6.

38. Kraut R, Patterson M, Lundmark V, Kiesler S, Mukopadhyay T, Scherlis W. Internet paradox: a social technology that reduces social involvement and psychological well-being? Am Psychol. 1998;53(9):101731. https://doi.org/10.1037/0003-066x.53.9.1017.

39. Leary MR. Responses to social exclusion: social anxiety, jealousy, loneliness, depression, and low selfesteem. J Soc Clin Psychol. 1990;9(2):221-9. https://doi.org/10.1521/jscp.1990.9.2.221.

40. Lee $\mathrm{YH}, \mathrm{Ko} \mathrm{CH}$, Chou C. Re-visiting internet addiction among Taiwanese students: a cross-sectional comparison of students' expectations, online gaming, and online social interaction. J Abnorm Child Psychol. 2015;43(3):589-99. https://doi.org/10.1007/s10802-014-9915-4.

41. Leung L. Linking psychological attributes to addiction and improper use of the mobile phone among adolescents in Hong Kong. J Child Media. 2008;2(2):93-113. https://doi.org/10.1080/17482790802078565.

42. Lin Y-H, Chiang C-L, Lin P-H, Chang L-R, Ko C-H, Lee Y-H, Lin S-H. Proposed diagnostic criteria for smartphone addiction. PLoS ONE. 2016;11(11):e0163010. https://doi.org/10.1371/journal.pone.0163010.

43. Łojko D, Suwalska A, Rybakowski J. Bipolar and related disorders and depressive disorders in DSM-5. Psychiatr Pol. 2014;48(2):245-60. 
44. Lu X, Watanabe J, Liu Q, Uji M, Shono M, Kitamura T. Internet and mobile phone text-messaging dependency: factor structure and correlation with dysphoric mood among Japanese adults. Comput Hum Behav. 2011;27(5):1702-9. https://doi.org/10.1016/j.chb.2011.02.009.

45. Matsuda M. Interpersonal relationships among young people and mobile phone usage: from attenuant to selective relationships. Jpn J Soc Info. 2000;11(4):111-22.

46. Mobile cellular subscriptions (per 100 people). In Data.Worldbank. Retrieved November 21, 2018 from https://data.worldbank.org/indicator/IT.CEL.SETS.P2.

47. Oberst U, Wegmann E, Stodt B, Brand M, Chamarro A. Negative consequences from heavy social networking in adolescents: the mediating role of fear of missing out. J Adolesc. 2017;55:51-60. https://doi.org/10.1016/j.adolescence.2016.12.008.

48. Pathak S. McCann Melbourne made up a word to sell a print dictionary: new campaign for Macquarie birthed 'phubbing'. Retrieved November 21, 2013 from http://adage.com/article/news/mccann-melbournemade-aword-sell-a-dictionary/244595/.

49. Peplau L, Perlman D. Perspectives on loneliness. In: Peplau L, Perlman D, editors. Loneliness: a sourcebook of current theory, research and therapy. New York: Wiley-Interscience; 1982. p. 1-20.

50. Perry SD, Lee KC. Mobile phone text messaging overuse among developing world university students. South Afr J Commun Theor Res. 2007;33(2):63-79. https://doi.org/10.1080/02500160701685417.

51. Radloff LS. The CES-D scale: a self-report depression scale for research in the general population. Appl Psychol Meas. 1977;1(3):385-401. https://doi.org/10.1177/014662167700100306.

52. Ray CM, Sormunen C, Harris TM. Men's and women's attitudes toward computer technology: a comparison. Office Syst Res J. 1999;17(1):1-8.

53. Rich AR, Bonner RL. Interpersonal moderators of depression among college students. J Coll Stud Pers. 1987;28(4):337-42.

54. Roberts JA, David ME. My life has become a major distraction from my cell phone: partner phubbing and relationship satisfaction among romantic partners. Comput Hum Behav. 2016;54:134-41. https://doi. org/10.1016/j.chb.2015.07.058.

55. Roberts JA, Petnji Yaya LH, Manolis C. The invisible addiction: cell-phone activities and addiction among male and female college students. J Behav Addict. 2014;3(4):254-65. https://doi.org/10.1556 /JBA.3.2014.015.

56. Sahin S, Ozdemir K, Unsal A, Temiz N. Evaluation of mobile phone addiction level and sleep quality in university students. Pakistan J Med Sci. 2013;29(4):913-8.

57. Salehan M, Negahban A. Social networking on smartphones: when mobile phones become addictive. Comput Hum Behav. 2013;29(6):2632-9. https://doi.org/10.1016/j.chb.2013.07.003.

58. Samaha M, Hawi NS. Relationships among smartphone addiction, stress, academic performance, and satisfaction with life. Comput Hum Behav. 2016;57(C):321-5. https://doi.org/10.1016/j. chb.2015.12.045.

59. Sánchez-Martínez M, Otero A. Factors associated with cell phone use in adolescents in the community of Madrid (Spain). CyberPsychol Behav. 2009;12(2):131-7. https://doi.org/10.1089/cpb.2008.0164.

60. Shambare R, Rugimbana R, Zhowa T. Are mobile phones the $21^{\text {st }}$ century addiction? Afr J Bus Manag. 2012;62(2):573-7. https://doi.org/10.5897/ajbm11.1940.

61. Smetaniuk P. A preliminary investigation into the prevalence and prediction of problematic cell phone use. J Behav Addict. 2014;3(1):41-53. https://doi.org/10.1556/jba.3.2014.004.

62. Takao M, Takahashi S, Kitamura M. Addictive personality and problematic mobile phone use. CyberPsychol Behav. 2009;12(5):501-7. https://doi.org/10.1089/cpb.2009.0022.

63. Wang X, Xie X, Wang Y, Wang P, Lei L. Partner phubbing and depression among married Chinese adults: the roles of relationship satisfaction and relationship length. Personal Individ Differ. 2017;110:12-7. https://doi.org/10.1016/j.paid.2017.01.014.

64. Yen CF, Tang TC, Yen JY, Lin HC, Huang CF, Liu SC, et al. Symptoms of problematic cellular phone use, functional impairment and its association with depression among adolescents in southern Taiwan. J Adolesc. 2009;32(4):863-73. https://doi.org/10.1016/j.adolescence.2008.10.006.

65. Yoo YS, Cho OH, Cha KS. Associations between overuse of the internet and mental health in adolescents. Nurs Health Sci. 2014;16:193-200. https://doi.org/10.1111/nhs. 12086.

66. Young KS. Internet addiction: the emergence of a new clinical disorder. CyberPsychol Behav. 1996;1(3): 237-44. https://doi.org/10.1089/cpb.1998.1.237.

67. Zhang Y, Zhou Y, Pei T. Mediating effect of loneliness on relationship between interpersonal adaptation and mobile phone addiction in college students. Chin Ment Health J. 2015;10:774-9.

Publisher's Note Springer Nature remains neutral with regard to jurisdictional claims in published maps and institutional affiliations. 
Ana Ivanova, Ph.D student in the Department of General Psychology, the John Paul II Catholic University of Lublin. Her research interest include psycholexical studies, social perception, and self-knowledge.

Oleg Gorbaniuk, Ph.D. is Associate Professor in the Department of General Psychology, the John Paul II Catholic University of Lublin and head of the Department of Psychological Research Methodology at the University of Zielona Góra. He earned his doctorate degree in the field of economics in 2000 and in psychology in 2001. In 2012, he received his post-doctoral title in economic psychology. His research focuses on social perception, psycholexical studies, methodology of marketing research, and consumer behavior.

Agata Blachnio, Ph.D with habilitation in Department of Emotion and Motivation Psychology at the Catholic University of Lublin. The main areas of scientific interests are focused on psychology of Internet, psychology of emotions, human behaviors as: dishonesty, disloyalty, academic cheating. Member of the International Association for Cross-Cultural Psychology (IACCP) and Polish Society of Social Psychology (PSPS).

Aneta Przepiórka, Ph.D. working at the Department of Emotion and Motivation Psychology, the John Paul II Catholic University of Lublin, Poland. Her research focuses on emotions (e.g. jealousy, betrayal), temporal perspective, and psychology of goals. Member of the International Association of Applied Psychology (IAAP), International Association for Cross-Cultural Psychology (IACCP) and Polish Society of Social Psychology (PSPS).

Natalia Mraka, $\mathrm{PhD}$ in Psychology, art-therapist working at the Department Psychology of Management, at the University of Internal Affairs of Lviv State. The main areas of scientific interests are focused on creativ psychology, studies from art-therapy, methodology of science research, differential psychology and motivation Psychology.

Viktoria Polishchuk, Master student, Department of Psychology and Pedagogy, National University of Ostroh Academy. Her research interest include cognitive psychology (e.g. metamemory, interference) and adaptation of migrants.

Julia Gorbaniuk, Ph.D. is Associate Professor at the John Paul II Catholic University of Lublin. He earned his doctorate degree in psychology in 2001 . His research focuses on social perception, family psychology, crosscultural psychology and psycholexical studies.

\title{
Affiliations
}

\section{Ana Ivanova ${ }^{1} \cdot$ Oleg Gorbaniuk $^{2} \cdot$ Agata Błachnio $^{1} \cdot$ Aneta Przepiórka $^{1}$. Natalia Mraka ${ }^{3}$ - Viktoria Polishchuk ${ }^{4}$ - Julia Gorbaniuk ${ }^{1}$}

\author{
1 John Paul II Catholic University of Lublin, Lublin, Poland \\ 2 Uniwersytet Zielonogórski, Góra, Poland \\ 3 L'viv State University of Internal Affairs, Lviv, Ukraine \\ 4 National University Ostroh Academy, Ostroh, Ukraine
}

